\title{
ANTIFUNGAL EFFICACY OF SECANG HEARTWOOD (CAESALPINIA SAPPAN L.) SOLUTIONS ON BIOFILMS OF CANDIDA ALBICANS ATCC 10231
}

\author{
BRINNA LISTIANI, RATNA MEIDYAWATI*, DEWA AYU NPA, DWI ARNIAWATY \\ Department of Conservative Dentistry, Faculty of Dentistry, Universitas Indonesia, Jakarta, 10430, Indonesia \\ Email: meidyawati58@gmail.com
}

Received: 27 August 2018, Revised and Accepted: 07 February 2019

\section{ABSTRACT}

Objective: Candida albicans is a predominant fungal species found in persistent root canal infection, and its virulence depends on the ability to form biofilms. To be able to eliminate this infection, a safe irrigation solution during root canal preparation is needed. This study is conducted to investigate the antifungal properties of secang heartwood extract solutions on C. albicans biofilm.

Methods: $C$. albicans biofilm was obtained from incubation of $C$. albicans ATCC 10231 at 96 -well plates in $37^{\circ} \mathrm{C}$ for $24 \mathrm{~h}$. These biofilms were exposed to various treatments: Secang heartwood in three different concentrations (25\%, 33\%, and 50\%), sodium hypochlorite (NaOCl) $2.5 \%$, and control group. The results of the treatment are to see the optical density (OD) value. The higher the OD values, the lower antifungal activity of the solution.

Results: The mean OD result from six samples obtained the mean value of various OD values showed in ELISA reader. Antifungal efficacy of 25\% secang heartwood was lower than concentration of 33\% and $50 \%$. All concentrations of secang heartwood showed higher OD values than $2.5 \% \mathrm{NaOCl}$ but lower than control group with $\mathrm{p}=0.01$.

Conclusion: Secang heartwood possesses antifungal effects against C. albicans biofilm but is lower than $2.5 \%$ NaOCl. Concentration of $25 \%$ has the strongest effect against $C$. albicans among other concentrations. This was a preliminary study of the antifungal efficacy of secang heartwood extract solutions against $C$. albicans biofilm. The result indicates that this solution has the potential to be used as an herbal alternative in root canal irrigations.

Keywords: Candida albicans, Biofilm, Secang heartwood, Optical density.

(C) 2019 The Authors. Published by Innovare Academic Sciences Pvt Ltd. This is an open access article under the CC BY license (http://creativecommons. org/licenses/by/4. 0/) DOI: http://dx.doi.org/10.22159/ijap.2019.v11s1.16060

\section{INTRODUCTION}

A major consideration in the treatment of endodontic failure is the elimination of dominant bacteria such as Enterococcus faecalis and fungi such as Candida albicans [1]. The ability of $C$. albicans to form biofilms provides a protective barrier in the form of an extracellular matrix and makes C. albicans thousands of times more resistant to phagocytosis, antibodies, and antimicrobial agents [2,3]. The long-term success of root canal treatment is affected by the cleaning, shaping, and disinfection of the root canals. Effective irrigation is essential because the anatomy of the complex root canal system reduces the effectiveness of instrumentation in root canal treatment [4].

The commonly used root canal irrigation solutions include sodium hypochlorite $(\mathrm{NaOCl})$, citric acid, and ethylenediaminetetraacetic acid (EDTA) [5]. In 2010, Fidalgo et al. studied the effectiveness of $\mathrm{NaOCl}$, 17\% EDTA, and citric acid on E. faecalis, C. albicans, and Staphylococcus aureus. Irrigation using 17\% EDTA resulted in better antifungal activity than $0.5 \% \mathrm{NaOCl}$ but showed the same effectiveness as $1 \% \mathrm{NaOCl}$ [6]. $\mathrm{NaOCl}$ at concentrations of $2.5 \%$ and $5.25 \%$ was more effective than $17 \%$ EDTA, and $5.25 \% \mathrm{NaOCl}$ had lethal effects on all microorganisms studied. Increasing the concentration of $\mathrm{NaOCl}$ not only increased its effectiveness but also resulted in increased toxicity. $2.5 \% \mathrm{NaOCl}$ can be recommended, as it has the same effectiveness as $5.25 \% \mathrm{NaOCl}$ but is less toxic [6]. There has been a report of $\mathrm{NaOCl}$ extrusion into periapical tissues including acute pain, swelling, hemorrhage, numbness, and secondary infection [7].

Caesalpinia sappan L., commonly referred to as Secang, is a medicinal plant widely used in Ayurveda and Chinese herbal medicine for treating tuberculosis, diarrhea, dysentery, skin infection, and anemia [8]. Brazilin, the major natural compound found in secang heartwood, has various biological activities, including antimicrobial activity [9-11]. In
2014, Kusmiati and Priadi studied the antimicrobial activity of secang heartwood, using ethanol as a solvent, at concentrations of $50 \%, 33 \%$, and $25 \%$ against planktonic $C$. albicans, and showed a maximum zone of inhibition of $14.65 \mathrm{~mm}$ in diameter with a concentration of $50 \%$ [12]. Hence, the purpose of this study is to assess the efficacy of secang heartwood extract solutions to C. albicans biofilm.

The present study aimed to compare the antifungal effects of the active ingredient of secang heartwood extract solution with $2.5 \% \mathrm{NaOCl}$ against biofilms of C. albicans ATCC 10231

\section{METHODS}

Secang heartwood preparation was done by macerated $2.5 \mathrm{~kg}$ of secang heartwood in $500 \mathrm{ml} 96 \%$ ethanol for $3 \mathrm{~h} \times 24 \mathrm{~h}$. The concentration process is carried out with rotary evaporator equipment at $80^{\circ} \mathrm{C}$ and continued to crystallization phase until thick extract solution of $100 \%$ secang heartwood is obtained. The solution was diluted using $10 \%$ dimethyl sulfoxide to obtain the desired concentrations, i.e., $25 \%$, $33 \%$, and $50 \%$, and stored at $4{ }^{\circ} \mathrm{C}$. The active ingredient brazilin was tested using high-performance liquid chromatography (HPLC). HPLC analysis was carried out using a binary HPLC pump with a photodiode array detector and an autosampler. The calibration curve of brazilin was established using authentic Brazilin at the concentration ranges of between 15.6 and $250 \mu \mathrm{g} / \mathrm{ml}$. The system used was as follows: A gradient program for $45 \mathrm{~min}$ from $5 \%$ to $100 \%$ methanol in $0.05 \%$ aqueous trifluoroacetic acid at a flow rate of $10 \mathrm{ml} / \mathrm{min}$. This preparation step gave crude brazilin, protosappanin $\mathrm{A}$, and sappanone $\mathrm{B}$.

C. albicans ATCC 10231 was cultured for $24 \mathrm{~h}$ at $37^{\circ} \mathrm{C}$ in Sabouraud Dextrose Broth (SDB), and the inoculum density results were calculated to obtain a suspension containing $1 \times 106$ cells $/ \mathrm{mL}$. 
Before biofilm examination, an inhibition zone test was performed to determine the optimal concentration of the secang heartwood extract that was required to eliminate $C$. albicans in planktonic cells. Determination of the optimum concentration of secang heartwood extract solution against $C$. albicans was performed by measuring the diameter of the inhibition zone using the concentrations of $25 \%, 33 \%$, and $50 \%$ secang heartwood, $\mathrm{NaOCl} 2.5 \%$, and control group. After the optimum dosage was obtained, then we continue to analyze the effect on $C$. albicans biofilm.

Antifungal activity against $C$. albicans biofilm was determined by adding $200 \mu \mathrm{L}$ of SDB solution containing C. albicans ATCC 10231 to a 96 -well plate and incubating at $37^{\circ} \mathrm{C}$ for $90 \mathrm{~min}$ to allow the cells to attach. The cells were then rinsed with $100 \mu \mathrm{L}$ of sterile phosphatebuffered saline (PBS), and then, $100 \mu \mathrm{L}$ of extract was added to the 96-well plates except the control group based on the design that was made before. Biofilm production was detected by measuring optical density (OD) in microtiter plate with ELISA reader. The Candida that is grown in Sabouraud's agar is added into $5 \mathrm{~mL}$ sterile saline with $0,85 \%$ concentration to density of a 0.5 McFarland nephalometer standard tube no 3 was matched with the growth of Candida in test tube which is approximately 107 cells / ml. Followed by a 1:20 dilution in Sabouraud's broth with a final concetration of $8 \%$ glucose. Then, $100 \mu \mathrm{L}$ of suspension was incubated at $37^{\circ} \mathrm{C}$ overnight in flat-bottomed 96-well microtiter plate for biofilm production. The microtiter plate was washed with PBS, and microtitre plate was stained with $110 \mu \mathrm{l}$ of $0.4 \%$ aqueous crystal violet solution for $45 \mathrm{~min}$. Afterward, each well was washed and destained with $200 \mu \mathrm{L}$ of $98 \%$ ethanol. After $45 \mathrm{~min}$ of destaining, the colorimetric change reading was taken in a microtiter plate reader at $492 \mathrm{~nm}$ using microtiter plate ELISA reader production (Lablife ER 2007 Microplate washer, DIAGNOVA)

The normality and homogeneity of the data were then analyzed using SPSS 22.0. The normality test using Shapiro-Wilk test beacuse the sample is $<50$. If the data were normally distributed and homogeneous, a one-way ANOVA statistical test was performed if there was a significant difference $(\mathrm{p}<0.05)$ and it was followed by Bonferroni post hoc test. One-way ANOVA was used to compare OD values in various treatments of $C$. albicans biofilm. The significance level considered in this study is 0.05 .

\section{RESULTS}

Measurement of antifungal activity of secang heartwood extract solution against $C$. albicans biofilm was performed by examining the OD value using microtiter ELISA reader; a low OD value represented low levels of fungi. Before biofilm examination, an inhibition zone test was performed to determine the optimal concentration of the secang heartwood extract that was required to eliminate C. albicans in planktonic cells (free-floating cells).

Table 1 shows that the mean inhibition zone diameter in the $50 \%$ concentration group was the greatest, with a value of $10.75 \mathrm{~mm}$. Oneway ANOVA results showed a significant $(\mathrm{p}<0.05)$ difference in the inhibition zone diameter in all study groups. Next, Bonferroni test was used to determine the effect of each concentration because the Levene test resulted in homogeneity of the studied variables. There was no significant difference between the $25 \%$ and $33 \%$ or the $33 \%$ and $50 \%$ secang extract solutions, whereas there was a significant difference between the $25 \%$ and $50 \%$ solutions $(p=0.001)$. Since there is no significant difference in all three concentrations, all the concentrations were used in this study to determine the antifungal activity of secang heartwood against $C$. albicans biofilm.

After exposing various treatment groups to C. albicans ATCC 10231 biofilm, the OD values obtained were normally distributed (Table 2). The lowest OD value was observed with $2.5 \% \mathrm{NaOCl}$ and the highest OD value was observed in the biofilms of the control group. The OD values at concentrations of $25 \%, 33 \%$, and $50 \%$ were lower than those for the untreated group, demonstrating the antifungal effects of secang heartwood extract on $C$. albicans biofilm

Higher concentrations of secang heartwood extract solution showed higher OD values, demonstrating lower antifungal activity of the solution (Table 2); therefore, the concentration of secang heartwood extract solution was not directly proportional to the antifungal effect on C. albicans biofilm.

One-way ANOVA showed that there was a significant difference in all treatment groups. A Bonferroni test is used to examine the relationship between each treatment group (Table 3). Post hoc Bonferroni is used because the Levene test showed that the data are homogenous. However, there was no significant difference between the antifungal effectiveness of $33 \%$ and $50 \%$ solutions against C. albicans biofilm.

\section{DISCUSSION}

The present study aimed to determine the antifungal effectiveness of secang heartwood extract solution on C. albicans ATCC 10231 biofilm. Microbiological studies of chronic apical periodontitis showed that C. albicans is the most common fungus found in around $7-18 \%$ of all infections. While the prevalence of fungi is relatively low, its presence is symbiotic with E. faecalis, which plays a role in the formation of persistent infection, especially in teeth that have undergone root canal

Table 1: Mean value of inhibition zone diameter (mm) after exposing C. albicans ATCC 10231 to various concentrations of secang heartwood extract solution

\begin{tabular}{lllll}
\hline Treatment group & n (sample) & Mean \pm SD & 95\% CI & p value \\
\cline { 3 - 4 } & & & Upper border & Lower border \\
\hline Secang heartwood extract, 25\% & 4 & $6.75 \pm 0.5$ & 5.9544 & 7.5456 \\
Secang heartwood extract, 33\% & 4 & $7.5 \pm 0.57$ & 6.58 & 8.4 \\
Secang heartwood extract, 50\% & 4 & $10.75 \pm 2.6$ & 6.56 & 14.9 \\
\hline
\end{tabular}

*One-way ANOVA, p<0.05, C. albicans: Candida albicans, SD: Standard deviation, CI: Confidence interval

Table 2: Mean OD values after exposing various treatment groups to $C$. albicans ATCC 10231 biofilm

\begin{tabular}{|c|c|c|c|c|c|}
\hline \multirow[t]{2}{*}{ Treatment groups } & \multirow[t]{2}{*}{$\mathbf{n}$} & \multirow[t]{2}{*}{ Mean \pm SD } & \multicolumn{2}{|l|}{$95 \% \mathrm{CI}$} & \multirow[t]{2}{*}{ p value } \\
\hline & & & Upper border & Lower border & \\
\hline Secang heartwood extract, $25 \%$ & 6 & $0.02133 \pm 0.005447$ & 0.015 & 0.27 & $* 0.001$ \\
\hline Secang heartwood extract, 33\% & 6 & $0.06108 \pm 0.0149$ & 0.045 & 0.076 & \\
\hline Secang heartwood extract, $50 \%$ & 6 & $0.8533 \pm 0.00689$ & 0.085 & 0.092 & \\
\hline $\mathrm{NaOCl}, 2.5 \%$ & 6 & $0.0045 \pm 0.001$ & 0.003 & 0.005 & \\
\hline Control & 6 & $0.2065 \pm 0.001$ & 0.20545 & 0.20755 & \\
\hline
\end{tabular}

*One-way ANOVA, p<0.05, NaOCl: Sodium hypochlorite, OD: Optical density, C. albicans: Candida albicans, SD: Standard deviation, CI: Confidence interval 
Table 3: Significance of difference in OD between treatment groups against biofilm of C. albicans ATCC 10231

\begin{tabular}{llllll}
\hline Treatment groups & $\begin{array}{l}\text { Secang heartwood } \\
\text { extract, 25\% }\end{array}$ & $\begin{array}{l}\text { Secang heartwood } \\
\text { extract, 33\% }\end{array}$ & $\begin{array}{l}\text { Secang heartwood } \\
\text { extract, 50\% }\end{array}$ & NaOCl 2.5\% & $\begin{array}{l}\text { Biofilm without } \\
\text { treatment }\end{array}$ \\
\hline Secang heartwood extract, 25\% & - & 0.007 & 0.000 & 0.005 & 0.000 \\
Secang heartwood extract, 33\% & & - & 0.082 & 0.002 & 0.000 \\
Secang heartwood extract, 50\% & & - & 0.000 & 0.000 \\
NaOCl, 2.5\% & & & - & 0.000 \\
Biofilm without treatment & & & & - \\
\hline
\end{tabular}

*Post-hoc Mann-Whitney U-test, $\mathrm{p} \leq 0.05$, NaOCl: Sodium hypochlorite, OD: Optical density, C. albicans: Candida albicans

treatment [13]. The success of antimicrobial agents in eliminating E. faecalis should also consider their ability to eliminate C. albicans. Successful elimination of $E$. faecalis accelerates the morphogenesis of C. albicans hyphae and increases the virulence of $C$. albicans, resulting in persistent endodontic infections that become increasingly difficult to eliminate $[14,15]$.

Secang heartwood is a herbal product known to contain brazilin compounds that can kill microorganisms [9]. Hangoluan also claimed the pharmacological activity of brazilin, including its antimicrobial activity [16].

The active ingredients in secang heartwood are extracted using ethanol as a solvent. Ethanol is considered a suitable solvent for extracting polyphenols and optimum levels of active compounds deemed safe for human consumption [17].

Batubara et al. previously reported the isolation of the active compound from secang heartwood using HPLC [18]. The present study was conducted in vitro using C. albicans ATCC 10231 samples capable of forming biofilms. The inhibition zone test in our study aimed to determine the most effective concentration in inhibiting the growth of C. albicans ATCC 10231 using secang heartwood at concentrations of $25 \%, 33 \%$, and $50 \%$, in accordance with a previous study by Kusmiati and Priadi [12].

In Table 1, the inhibitory zone test shows that higher concentrations of secang solution (the bold font) resulted in a larger diameter of inhibition zone. This is in accordance with the results reported by Kusmiati and Priadi, who stated that higher concentrations of extracts of secang showed a greater diameter of growth inhibition against microorganisms, indicating a higher efficacy of secang heartwood extract solution as an antimicrobial agent [12].

Table 2 shows that the lowest concentration of secang extract revealed the lowest $\mathrm{OD}$ value, demonstrating that the lower the concentration, the greater the antifungal ability of secang heartwood solution against C. albicans biofilm.

However, the difference between the results of the inhibition zone and OD value tests on $C$. albicans biofilm could be due to differences in the diffusion ability of each concentration of extract into the $C$. albicans membrane; the lower the concentration, the lower the viscosity of the extract solution, resulting in easier penetration of the solution into the fungal membrane leading to interference with the metabolic processes of $C$. albicans. Another possibility is that the greater the concentration, the more dense coloring of the solution of secang heartwood solution. The crystal violet coloration used in the OD value test not only showed color changes occurring in the cell but also the secang solutions color attached to the surface of the plate; therefore, it may have overestimated the number of microorganism cells attached $[7,14,15]$.

In the present study, $2.5 \% \mathrm{NaOCl}$ showed greater antifungal ability than secang heartwood solutions from the three concentrations studied through the antimicrobial effect of chlorine-inhibiting enzymes in the fungus, leading to oxidation of sulfhydryl group in the fungal enzyme. Hypochlorite acid and hypochlorite ions result in the degradation of amino acids and hydrolysis [16]. This is in line with the findings of
Spencer et al., which showed that $2.5 \% \mathrm{NaOCl}$ as a root canal irrigant had better antifungal potential against $C$. albicans than chlorhexidine, MTAD, and EDTA 17\% [6,13].

The antifungal mechanism of Secang wood is derived from Brazilin, the main active ingredient [19]. Brazilin is a derivative of flavonoids belonging to the phenol class as a secondary metabolite of secang and belongs to a 3-benzychroman derivative [20]. The antifungal mechanisms of brazilin have not only been clearly defined but also are thought to be similar to those of phenols, which penetrate into the cell nucleus after denaturing protein bonds and lysing the cell membrane. Phenols bind through their hydroxyl group to the sulfhydryl group of fungal proteins to alter the cell membrane protein and inhibit fungal enzymes such as cellulase, pectinase, and lactase. They also cause a deficiency of nutrient substrates, such as metal complex and insoluble protein, and inhibit oxidative phosphorylation [17]. Based on toxicological studies of $C$. sappan by Athinarayanana et al., there were no death rats recorder as a result of oral treatment to the test plant sample and none of the test dye samples exhibited any sign of toxicity/ adverse reactions in the animal models used in the study [21].

The unique structure of brazilin, such as the hydroxyl group at the seventh position (7- oxygenation), the hydroxyl substituent at C4, and the double bond at $\mathrm{C} 2-\mathrm{C} 3$, plays the roles in its effectiveness as an antifungal agent $[3,18]$.

\section{CONCLUSION}

Secang heartwood has antifungal effects on biofilms of $C$. albicans ATCC 10231. Increasing the concentration of secang heartwood extract solution does not lead to a directly proportional antifungal effect on C. albicans biofilm. The antifungal effect of $25 \%$ secang heartwood extract solution was the most effective concentration of $C$. albicans biofilm compared with other concentrations of secang heartwood extract solution; however, $2.5 \% \mathrm{NaOCl}$ showed the best antifungal effects among the studied treatments against biofilm $C$. albicans. The use of secang heartwood extract solution as an antifungal of endodontic irrigant can be helpful since it is biocompatible to surrounding tissues and lack of serious risk compared to $\mathrm{NaOCl}$. Pre-clinical and clinical trials are recommended for evaluating its safety and biocompatibility before its use as an intracanal irrigating solution in the clinical setting.

\section{ACKNOWLEDGMENTS}

This study was supported by the Directorate of Research and Community Engagement of Universitas Indonesia. The publication of this manuscript was supported by Universitas Indonesia.

\section{CONFLICTS OF INTEREST}

There are no conflicts of interest to declare.

\section{REFERENCES}

1. Kumar J, Sharma R, Sharma M, Prabhavathi V, Paul J, Chowdary CD, et al. Presence of Candida albicans in root canals of teeth with apical periodontitis and evaluation of their possible role in failure of endodontic treatment. J Int Oral Health 2015;7:42-5.

2. Tyagi SP, Sinha DJ, Garg P, Singh UP, Mishra CC, Nagpal R, et al. Comparison of antimicrobial efficacy of propolis, Morinda citrifolia, 
Azadirachta indica (Neem) and 5\% sodium hypochlorite on Candida albicans biofilm formed on tooth substrate: An in-vitro study. J Conserv Dent 2013;16:532-5.

3. Rao S, Agnihotri Y, Bai P, Padmanabhan P, Das S. Isolation of fungal hyphae in periapical infection. J Indian Acta Oral Med Radiol 2013;25:221-4.

4. Arias-Moliz MT, Ordinola-Zapata R, Baca P, Ruiz-Linares M, García García E, Hungaro Duarte MA, et al. Antimicrobial activity of chlorhexidine, peracetic acid and sodium hypochlorite/etidronate irrigant solutions against Enterococcus faecalis biofilms. Int Endod J 2015;48:1188-93.

5. Haapasalo M, Shen Y, Qian W, Gao Y. Irrigation in endodontics. Dent Clin North Am 2010;54:291-312.

6. Fidalgo TK, Barcelos R, Portela MB, Soares RM, Gleiser R, Silva-Filho FC, et al. Inhibitory activity of root canal irrigants against Candida albicans, Enterococcus faecalis and Staphylococcus aureus. Braz Oral Res 2010;24:406-12.

7. Faras F, Abo-Alhassan F, Sadeq A, Burezq H. Complication of improper management of sodium hypochlorite accident during root canal treatment. J Int Soc Prev Community Dent 2016;6:493-6.

8. Bukke AN, Hadi FN, Produtur CS. Comparative study of in vitro antibacterial activity of leaves, bark, heart wood and seed extracts of Caesalpinia sappan L. Asian Pac J Trop Dis 2015;5:903-7.

9. Nirmal NP, Panichayupakaranant P. Antioxidant, antibacterial, and anti-inflammatory activities of standardized Brazilin-rich Caesalpinia sappan extract. Pharm Biol 2015;53:1339-43.

10. Puttipan R, Chansakaow S, Khongkhunthian S, Okonogi S. Caesalpinia sappan: A promising natural source of antimicrobial agent for inhibition of cariogenic bacteria. Drug Discov Ther 2018;12:197-205.

11. Hwang HS, Shim JH. Brazilin and Caesalpinia sappan L. Extract protect epidermal keratinocytes from oxidative stress by inducing the expression of GPX7. Chin J Nat Med 2018;16:203-9.

12. Kusmiati D, Priadi D. Analisa senyawa aktif ekstrak kayu secang (Caesalpinia sappan L.) yang berpotensi sebagai antimikroba. Teknol Ind Hijau 2014;2014:169-74.

13. Poptani B, Sharaff M, Archana G, Parekh V. Detection of Enterococcus faecalis and Candida albicans in previously root-filled teeth in a population of Gujarat with polymerase chain reaction. Contemp Clin Dent 2013;4:62-6.

14. Chua EG, Parolia A, Ahlawat P, Pau A, Amalraj FD. Antifungal effectiveness of various intracanal medicaments against Candida albicans: An ex-vivo study. BMC Oral Health 2014;14:53.

15. Mergoni G, Percudani D, Lodi G, Bertani P, Manfredi M. Prevalence of Candida species in endodontic infections: Systematic review and metaanalysis. J Endod 2018;44:1616-25000000000.

16. Hangoluan BY. Pengembangan Metode Isolasi Brazilin Dari Kayu Secang (Caesalpinia sappan). Bogor: Institut Pertanian Bogor; 2011.

17. Do QD, Angkawijaya AE, Tran-Nguyen PL, Huynh LH, Soetaredjo FE, Ismadji S, et al. Effect of extraction solvent on total phenol content, total flavonoid content, and antioxidant activity of Limnophila aromatica. J Food Drug Anal 2014;22:296-302.

18. Batubara I, Mitsunaga T, Ohashi H. Brazilin from Caesalpinia sappan wood as an antiacne agent. J Wood Sci 2010;56:77-81.

19. Chang Y, Huang SK, Lu WJ, Chung CL, Chen WL, Lu SH, et al. Brazilin isolated from Caesalpinia sappan L. Acts as a novel collagen receptor agonist in human platelets. J Biomed Sci 2013;20:4.

20. Fu LC, Huang XA, Lai ZY, Hu YJ, Liu HJ, Cai XL, et al. A new 3-benzylchroman derivative from sappan lignum (Caesalpinia sappan). Molecules 2008;13:1923-30.

21. Athinarayanana G, Ranjitsingh A, Nanthini AU, Padmalatha C. Toxicological studies of Caesalpinia sappan wood derived dye in Wister albino rats. Food Sci Hum Wellness 2017;6:34-8. 